\title{
Penggunaan Media Booklet Ibu Hamil dalam Upaya Pencegahan Anemia pada Ibu Hamil Korban Tsunami
}

\section{The Using of Pregnant Women Booklets in Efforts to Prevent Anemia in Pregnant Women of Tsunami Victims}

\author{
Indah Trianingsih ${ }^{1}$, Marlina $^{2}$ \\ Jurusan Kebidanan, Politeknik Kesehatan Tanjung Karang, Indonesia
}

\section{ARTICLE INFO}

\section{Article history}

Received date

13 August 2020

Revised date

19 August 2020

27 August 2020

Accepted date

08 Sept 2020

\section{Keywords:}

Anemia;

Booklet;

Knowledge,

Pregnant women

Kata kunci:

Anemia;

Booklet;

Pengetahuan;

Ibu hamil.

\begin{abstract}
ABSTRAK
Anemia has a high contribution to mortality in Indonesia with a percentage of 50-70\%. The research objective was to determine the benefits of booklet media to prevent anemia in pregnant women victims of the tsunami in the South Lampung area which occurred in December 2018. The research design was pre-experimental with one group pre-test and post-test research designs. The population of this study was pregnant women who were in the South Lampung area which was affected by the December 2018 tsunami. The number of samples was the total population taken randomly. Quantitative data analysis using frequency distribution, independent T-test. Based on the results of the Wilcoxon Matched Pairs statistical test, the effectiveness of the pregnant women booklet on HB levels, the value of $\alpha=0,000$ was obtained, so that $\alpha<0,05$. The results of this statistical test prove that the booklet of pregnant women is effective on the HB level of pregnant women. Likewise, in the booklet effectiveness test of pregnant women on maternal knowledge, the value of $\alpha=0,000$ was obtained so that $\alpha<0,05$. Thus it can be concluded that there is the effectiveness of pregnant women booklets in efforts to prevent anemia in pregnant women victims of the tsunami in the South Lampung area in 2019.
\end{abstract}

Anemia memiliki kontribusi yang tinggi terhadap kematian di Indonesia dengan persentase mencapai $50-70 \%$. Tujuan penelitian mengetahui manfaat media booklet dalam upaya pencegahan anemia pada ibu hamil korban tsunami di daerah Lampung Selatan yang terjadi pada Desember 2018. Desain penelitian ini bersifat pre eksperimen dengan desain penelitian one group pre test dan post test. Populasi penelitian ini adalah ibu hamil yang berada di wilayah Lampung Selatan yang terdampak tsunami Desember 2018. Jumlah sampel adalah total populasi yang diambil secara acak. Analisis data kuantitatif menggunakan distribusi frekuensi, T-Test independent. Berdasarkan hasil uji statistik Wilcoxon Matched Paires efektivitas booklet ibu hamil terhadap kadar $\mathrm{Hb}$, didapatkan nilai $\alpha=0,000$ sehingga $\alpha<0,05$. Hasil uji statistik ini membuktikan terdapat efektivitas booklet ibu hamil terhadap kadar $\mathrm{Hb}$ ibu hamil. Demikian juga pada uji efektivitas booklet ibu hamil terhadap pengetahuan ibu, didapatkan nilai $\alpha=0,000$ sehingga $\alpha<0,05$. Dengan demikian dapat disimpulkan terdapat efektivitas booklet ibu hamil dalam upaya pencegahan anemia pada ibu hamil korban tsunami di daerah Lampung Selatan Tahun 2019.

\section{Corresponding Author:}

Indah Trianingsih

Jurusan Kebidanan, Politeknik Kesehatan Tanjung Karang, Indonesia

Email: indaheffendi@yahoo.com

\section{PENDAHULUAN}

Angka kematian ibu di Indonesia relatif tinggi, berdasarkan SDKI tahun 2012, AKI di Indonesia sebesar 118 per 100.000 kelahiran hidup, sedangkan AKI di Propinsi Lampung mencapai 359 per 100.000 kelahiran hidup (Dinas Kesehatan Provinsi Lampung, 2017). Adapun penyebab kasus kematian ibu di Provinsi Lampung tahun 2017 antara lain perdarahan 
$37 \%$, hipertensi dalam kehamilan $20 \%$, infeksi $3 \%$, gangguan system peredaran darah $15 \%$, gangguan metabolik 3\%, dan lain-lain 22\% (Dinas Kesehatan Provinsi Lampung, 2017).

Anemia juga memiliki kontribusi yang tinggi terhadap kematian di Indonesia dengan persentase mencapai $50-70 \%$. Berdasarkan laporan Riskesdas tahun 2018 disebutkan bahwa prevalensi anemia sebesar 48,9\% mengalami peningkatan dibandingkan hasil Riskesdas tahun 2013 yakni $37,1 \%$. Tidak terdapat perbedaan signifikan antara prevalensi anemia ibu hamil di perkotaan $(36,4 \%)$ dan di perdesaan $(37,8 \%)$. Anemia adalah suatu keadaan kadar hemoglobin $(\mathrm{Hb})$ di dalam darah lebih rendah daripada nilai normal untuk kelompok orang menurut umur dan jenis kelamin. Secara umum, penyebab utama anemia adalah defisiensi besi sehingga defisiensi zat besi dan anemia sering diartikan sama (Kementerian Kesehatan, RI., 2018).

Kegiatan suplementasi zat besi merupakan penanggulangan anemia yang paling banyak dilakukan, dimana di Indonesia pemberian tablet besi pada ibu hamil sudah dilakukan sejak tahun 1975. Tablet besi atau tablet tambah darah diberikan pada ibu hamil sebanyak 1 tablet setiap hari berturut-turut selama 90 hari selama masa kehamilan. Tablet tambah darah tersebut sebaiknya diminum sejak awal kehamilan 1 tablet sehari (Kementerian Kesehatan RI, 2016). Akan tetapi hasilnya belum menggembirakan, dimana beberapa literatur dari berbagai negara mengatakan ketidakpatuhan ibu hamil merupakan faktor yang signifikan dari kegagalan program suplementasi zat besi (Subagyo, 2002). Ketidakpatuhan ibu hamil dalam mengkonsumsi suplementasi zat besi dipengaruhi oleh berbagai faktor, diantaranya adalah pengetahuan, motivasi, peranan keluarga dan perilaku petugas kesehatan. Tren cakupan ibu hamil yang mendapatkan $\mathrm{Fe} 3$ di propinsi Lampung berfluktuasi, dimana tahun 2015 mencapai $83 \%$, tahun 2016 mencapai 89,53\%, dan tahun 2017 turun $89,4 \%$. Pada kabupaten Lampung Selatan Cakupan bumil anemia pada tahun 2017 sebesar $2,2 \%$, angka ini lebih tinggi dari cakupan anemia di Bandar Lampung yang sebesar 1,5 (Dinas Kesehatan Provinsi Lampung, 2017). Kabupaten Lampung Selatan pada tanggal 22 Desember 2012 terkena bencana Tsunami, dalam penanggulangan bencana alam tersebut 12 posko pengungsian di masing-masing wilayah yang terkena bencana tersebut. Hasil rekapan Dinas Kesehatan Lampung Selatan terdapat 111 Ibu Hamil yang mendapatkan pelayanan kesehatan di 12 Posko tersebut.
Pengetahuan merupakan salah satu faktor yang mempengaruhi terbentuknya perilaku kesehatan. Apabila ibu hamil mengetahui dan memahami akibat anemia dan cara mencegah anemia maka akan mempunyai perilaku kesehatan yang baik sehingga diharapkan dapat terhindar dari berbagai akibat atau resiko terjadinya anemia kehamilan. Perilaku kesehatan yang demikian dapat berpengaruh terhadap penurunan kejadian anemia pada ibu hamil (Purbadewi, 2013).

Menurut Kemm dan Close (dalam Roza, 2012), ada dua kelebihan booklet dibandingkan dengan media lain yaitu dapat dipelajari setiap saat, karena didesain mirip dengan buku dan dapat memuat informasi relatif lebih banyak dibandingkan dengan poster.

Pemberian booklet ibu hamil ini diharapkan juga dapat membantu tenaga kesehatan lainnya terkait pemberian informasi tentang tablet tambah darah yang efisien kepada setiap ibu hamil. Karena tidak terikat oleh waktu kerja, poin-poin informasi yang ingin diberikan dapat tersampaikan dengan baik sehingga dapat digunakan dalam praktek pelayanan kesehatan secara luas. Hasil akhir yang diharapkan dengan meningkatnya pengetahuan ibu, kepatuhan ibu hamil untuk mengkonsumsi tablet tambah darah juga meningkat, sehingga terdapat kenaikan kadar $\mathrm{Hb}$ pada ibu hamil.

Kabupaten Lampung Selatan yang pada tanggal 22 Desember 2018 terkena Tsunami telah mendirikan sebanyak 12 Posko Pengungsian di wilayah yang terkena tsunami. Dari 12 posko pengungsian tersebut terdapat $111 \mathrm{ibu}$ hamil. Oleh karena itu peneliti tertarik untuk mengetahui pengaruh pengunaan media booklet ibu hamil dalam upaya pencegahan anemia pada ibu hamil korban tsunami di daerah Lampung Selatan.

\section{METODE}

Penelitian ini merupakan penelitian yang bersifat pre eksperimen dengan desain penelitian one group pre-test dan post-test. Variabel independen dalam penelitian ini adalah gerakan pencegahan anemia berupa pendidikan kesehatan dengan menggunakan booklet ibu hamil. Sedangkan variabel dependen adalah pengetahuan dan kadar $\mathrm{Hb}$ ibu hamil sebelum dan setelah diintervensi.

Lokasi penelitian ini di wilayah Kecamatan Rajabasa, Kabupaten Lampung Selatan yang terdampak tsunami pada Desember 2018 yang lalu, meliputi Desa Seragi, Desa 
Banding, Desa Way Muli, dan Desa Pulau Subesi. Penelitian dilaksanakan dari bulan Maret-Desember 2019. Populasi dalam penelitian ini adalah seluruh ibu hamil yang berada di wilayah Kabupaten Lampung Selatan yang terdampak tsunami Desember 2018, yaitu 98 orang. Teknik sampling yang digunakan dalam penelitian ini adalah systematic random sampling dengan kriteria inklusi, yaitu ibu hamil yang terkena bencana tsunami selat sunda meliputi Desa Seragi, Desa Banding, Desa Way Muli, dan Desa Pulau Sebesi, hamil dengan usia 14-27 minggu, hamil dengan resiko kehamilan yang rendah, Ibu hamil yang dapat membaca, menulis, dan berkomunikasi dengan lancer, dan bersedia menjadi sampel penelitian. Sedangkan kriteria eksklusi, yaitu ibu hamil yang tidak bisa baca tulis dan dalam keadaan sakit kronis.

Instrumen yang digunakan pada penelitian ini berupa angket seputaran anemia yang diisi sebelum intervensi dan sesudah intervensi, serta digunakan $\mathrm{Hb}$ digital untuk mengukur kadar hemogloblin ibu yang dilakukan oleh enumerator (bidan). Proses pengolahan data dengan menggunakan Uji Wilcoxon.

Penelitian ini telah melewati kaji etik dan mendapatkan Persetujuan Etik dari Komisi Etik Penelitian Kesehatan Politeknik Kesehatan Tanjung Karang Nomor: 245/EA/KEPKTJK/VIII/2019.

\section{HASIL}

Tabel 1. Karakteristik Responden

\begin{tabular}{lrr}
\hline Karakteristik & Frekuensi & \multicolumn{1}{c}{$\%$} \\
\hline Umur & & \\
20-35 tahun & 28 & 65,1 \\
36-40 tahun & 15 & 34,9 \\
\hline Paritas & & \\
Primigravida & 15 & 34,9 \\
Multigravida & 25 & 58,1 \\
Grandegravidarum & 3 & 7 \\
\hline Pendidikan & & \\
SD & 2 & 4,7 \\
SMP & 17 & 39,5 \\
SMA & 22 & 51,1 \\
D3/S1/S2 & 2 & 4,7 \\
\hline
\end{tabular}

Berdasarkan tabel 1 diketahui bahwa sebagian besar umur responden di Kecamatan Rajabasa Lampung Selatan adalah 20-30 tahun sebanyak 28 orang $(65,1 \%)$, pada paritas paling banyak adalah multigravida 25 orang $(58,1 \%)$, Pada pendidikan paling banyak pendidikan SMA yaitu sebanyak 22 orang $(51,1 \%)$.
Tabel 2. Hasil Uji Normalitas terhadap Kadar Hb Ibu Hamil dan Pengetahuan Ibu Hamil

\begin{tabular}{lrr}
\hline \multirow{2}{*}{ Variabel } & \multicolumn{2}{c}{$\boldsymbol{p}$-value } \\
\cline { 2 - 3 } & Pre-test & Post-test \\
\hline Kadar $\mathrm{Hb}$ & 0,002 & 0,000 \\
\hline Pengetahuan & 0,020 & 0,000 \\
\hline
\end{tabular}

Tabel 2 menunjukkan bahwa data kadar $\mathrm{Hb}$ ibu hamil sebelum diberikan booklet ibu hamil dan tablet $\mathrm{Fe}$ memiliki nilai kemaknaan 0,002 sedangkan nilai kemaknaan kadar $\mathrm{Hb}$ setelah diberikan booklet ibu hamil dan tablet $\mathrm{Fe}$ sebesar 0,000. Kedua data tersebut memiliki nilai kemaknaan $\quad \alpha<0,05$. Kemudian, tingkat pengetahuan sebelum diberikan booklet ibu hamil memiliki nilai kemaknaan 0,020 sedangkan nilai kemaknaan tingkat pengetahuan setelah diberikan booklet ibu hamil sebesar 0,000. Kedua data tersebut memiliki nilai kemaknaan $\alpha<0,05$. Dapat disimpulkan bahwa data yang diperoleh tidak berdistribusi normal, sehingga uji hipotesis yang digunakan dalam penelitian ini adalah jenis uji statistik non-parametik yaitu uji Wilcoxon.

Tabel 3. Kadar Hb Ibu hamil Korban Tsunami sebelum dan sesudah pemberian Booklet Ibu Hamil dan Tablet FE

\begin{tabular}{|c|c|c|c|c|c|}
\hline $\begin{array}{c}\text { Kadar } \\
\text { Hb } \\
\text { Sebelum } \\
\text { Intervensi }\end{array}$ & Jlh & $\%$ & $\begin{array}{c}\text { Kadar Hb } \\
\text { Sesudah } \\
\text { Intervensi }\end{array}$ & Jlh & $\%$ \\
\hline Anemia & 18 & 41,9 & Anemia & 0 & 0 \\
\hline $\begin{array}{l}\text { Tidak } \\
\text { Anemia }\end{array}$ & 25 & 58,1 & $\begin{array}{l}\text { Tidak } \\
\text { Anemia }\end{array}$ & 43 & 100 \\
\hline
\end{tabular}

Berdasarkan tabel 3 diketahui bahwa dari 43 responden di Kecamatan Rajabasa Kabupaten Lampung Selatan Tahun 2019 sebelum pemberian booklet ibu hamil dan tablet $\mathrm{Fe}$ masih terdapat 18 orang ibu hamil (41,9\%) yang mengalami anemia dan setelah pemberian booklet ibu hamil dan tablet Fe keseluruhan (100\%) ibu hamil tidak menderita anemia.

Tabel 4. Pengetahuan Ibu hamil Korban Tsunami sebelum dan sesudah pemberian Booklet Ibu Hamil

\begin{tabular}{lcrr}
\hline & n & Mean & $\begin{array}{c}\text { Std } \\
\text { Deviation }\end{array}$ \\
\hline Nilai Pre-test & 43 & 61,98 & 15,2 \\
\hline Nilai Post-test & 43 & 78,49 & 12,8 \\
\hline
\end{tabular}

Berdasarkan tabel 4 diketahui bahwa pengetahuan responden sebelum diberikan booklet ibu hamil adalah 61,98 dengan standar deviasi 15,2, Setelah pemberian booklet ibu 
hamil rata-rata pengetahuan responden menjadi 78,49 dengan standar deviasi 12,8 .

Tabel 5. Pengaruh Penggunaan Booklet Ibu Hamil dan Tablet Fe terhadap Kadar Hb Ibu Hamil

\begin{tabular}{clcccc}
\hline & N & & $\begin{array}{c}\text { Mean } \\
\text { Rank }\end{array}$ & $\begin{array}{c}\text { Sum } \\
\text { of } \\
\text { Rank }\end{array}$ & $\begin{array}{c}\boldsymbol{p} \text { - } \\
\text { value }\end{array}$ \\
\hline $\mathrm{Hb}$ & Negative & $2^{\mathrm{a}}$ & 10,00 & 20,00 & \\
$\mathrm{Akhir}$ & Ranks & & & & \\
$-\mathrm{Hb}$ & Positive & $27^{\mathrm{b}}$ & 15,37 & 415,00 & 0,000 \\
$\mathrm{Awal}$ & Ranks & & & & \\
& Ties & $14^{\mathrm{c}}$ & & & \\
& Total & 43 & & & \\
\hline
\end{tabular}

Berdasarkan tabel 5 dari 43 responden yang telah diberikan intervensi berupa booklet Ibu Hamil dan tablet Fe, terdapat 2 ibu hamil yang mengalami penurunan $\mathrm{Hb}, 27$ orang mengalami kenaikan $\mathrm{Hb}$, dan 14 orang memiliki $\mathrm{Hb}$ awal dan akhir yang sama. Output test statististik nilai Asymp.sig (2 tailed) untuk kadar $\mathrm{Hb}$ ibu hamil sebelum dan sesudah diberikan perlakuan sebesar 0,000 , yang berarti nilai Asymp.Sig $(2$ tailed $)<\rho$-value $(\rho$-value $=0,05)$. Hasil tersebut menunjukkan bahwa Ha diterima dan Ho ditolak yang berarti ada efektivitas booklet ibu hamil dan pemberian tablet $\mathrm{Fe}$ terhadap kadar $\mathrm{Hb}$ ibu hamil korban tsunami di Kabupaten Lampung Selatan tahun 2019.

Tabel 6. Efektivitas Booklet Ibu Hamil Terhadap Tingkat Pengetahuan Ibu Hamil

\begin{tabular}{llrrrr}
\hline & $\mathbf{N}$ & & $\begin{array}{c}\text { Mean } \\
\text { Rank }\end{array}$ & $\begin{array}{c}\text { Sum } \\
\text { Of } \\
\text { Rank }\end{array}$ & $\begin{array}{c}\boldsymbol{p} \text { - } \\
\text { value }\end{array}$ \\
\hline $\begin{array}{l}\text { Post } \\
\text {-test }\end{array}$ & $\begin{array}{l}\text { Negative } \\
\text { Ranks }\end{array}$ & 0a & 0,00 & 0,00 & \\
- & Positive & $39^{\mathrm{b}}$ & 20,00 & 780,0 & 0,000 \\
Pre- & Ranks & & & 0 & \\
test & Ties & $4^{\mathrm{c}}$ & & & \\
& Total & 43 & & & \\
\hline
\end{tabular}

Berdasarkan tabel 6 dari 43 responden yang telah diberikan intervensi berupa booklet Ibu Hamil dan tablet $\mathrm{Fe}$, menunjukan tidak ada ibu hamil yang mengalami penurunan pengetahuan, 39 orang mengalami kenaikan pengetahuan, dan 4 orang memiliki pengetahuan awal dan akhir yang sama.

Berdasarkan output test statististik nilai $p$ value untuk pengetahuan ibu hamil sebelum dan sesudah diberikan perlakuan sebesar 0,000 , yang berarti nilai Asymp.Sig (2 tailed) $<\rho$-value $(\rho$ value $=0,05$ ). Hasil tersebut menunjukkan bahwa Ha diterima dan Ho ditolak yang berarti ada efektivitas booklet ibu hamil dan pemberian tablet $\mathrm{Fe}$ terhadap pengetahuan ibu hamil korban tsunami di Kabupaten Lampung Selatan tahun 2019.

\section{PEMBAHASAN}

\section{Kadar Hemogloblin pada Ibu Hamil Sebelum dan Sesudah diberikan Booklet Ibu Hamil}

Pada uji analisis pengaruh penggunaan Booklet ibu Hamil dan Tablet Fe Terhadap Kadar $\mathrm{Hb}$ ibu hamil korban tsunami di Kabupaten Lampung Selatan Tahun 2019 menggunakan Uji Wilcoxon didapatkan output test statististik nilai Asymp.sig (2 tailed) untuk kadar $\mathrm{Hb}$ ibu hamil sebelum dan sesudah diberikan perlakuan sebesar 0,000 yang berarti nilai Asymp.Sig $(2$ tailed $)<\rho$-value $(\rho$ value $=0,05$ ). Hasil tersebut menunjukkan bahwa ada pengaruh penggunaan booklet ibu hamil dan pemberian tablet $\mathrm{Fe}$ terhadap kadar $\mathrm{Hb}$ ibu hamil korban tsunami di Kabupaten Lampung Selatan tahun 2019.

Hal ini sesuai dengan penelitian Subarda (2011), dimana ibu hamil yang mendapatkan pelayanan ANC tidak baik mempunyai peluang 82 kali lebih tinggi untuk tidak patuh minum tablet besi dibandingkan ibu hamil yang mendapat pelayanan ANC baik. Dalam pelayanan ANC ibu hamil akan mendapatkan informasi yang berkualitas tentang kesehatan selama kehamilan. Dimana dalam pemberian informasi kesehatan kehamilan Petugas kesehatan biasanya menggunakan konsulatsi seperti booklet Ibu Hamil yang memuat informasi mengenai anemia dan tablet tambah darah.

Hal ini juga sesuai dengan penelitian Aditianti (2015), dimana terdapat hubungan yang signifikan antara tingkat pengetahuan ibu hamil dengan tingkat kepatuhan $\rho$-value $=0,02$. Hal ini berarti makin tinggi tingkat pengetahuan akan semakin patuh pula ibu hamil mengkonsumsi tablet $\mathrm{Fe}$.

Selama ini ibu hamil enggan mengkonsumsi obat karena dalam pemikiran mereka tablet $\mathrm{Fe}$ berarti obat dimana obat untuk orang sakit. Sedangkan kehamilan mereka tidak dirasakan sebagai kondisi sakit yang perlu diobati. Terlebih lagi adanya pemikiran bahwa jaman dulu orang hamil tanpa tambahan obat apapun, anaknya sehat dan bisa melahirkan dengan lancer. Ada juga yang khawatir jika terlalu banyak mengkonsumsi $\mathrm{Fe}$ (obat) kehamilannya akan besar dan justru dianggap menyulitkan persalinan Triratnawati (1998). Belum lagi efek samping Fe seperti perut terasa 
tidak enak, mual-mual, Susah BAB dan tinja berwarna hitam.

Untuk itu sebaiknya petugas memberikan penjelasan tentang manfaat $n$ efek samping dari tablet $\mathrm{Fe}$ dengan menggunakan media seperti booklet ibu hamil, sehingga ibu hamil dapat memahami bahwa Tablet Fe sangat diperlukan sebagai alternatif dalam mengatasi peningkatan kebutuhan zat besi selama kehamilan juga cara untuk meminimalisir efek samping dari meminum Tablet Fe.

Begitu juga dengan penelitian Robiatul (2013), dimana dalam pengukuran kadar $\mathrm{Hb}$ awal ibu hamil pada kelompok uji menunjukkan bahwa sebanyak $8 \%$ ibu hamil yang mengalami anemia dan $92 \%$ tidak mengalami anemia. Kemudian pada pengukuran kadar $\mathrm{Hb}$ akhir menggambarkan $100 \%$ ibu hamil tidak mengalami anemia. Pada penelitian ini, edukasi disampaikan melalui booklet yang mewakili penyampaian tentang anemia dan penggunaan tablet tambah darah terhadap ibu hamil. Hal ini berarti penggunaan booklet Ibu Hamil dan konsumsi tablet $\mathrm{Fe}$ dapat mengurangi kejadian anemia pada ibu hamil.

Sesuai dengan teori Kemm dan Close (dalam Roza, 2012), bahwa media booklet dapat dipelajari setiap saat, karena didesain mirip dengan buku dan dapat memuat informasi relatif lebih banyak dibandingkan dengan poster. Dengan adanya media booklet tersebut, ibu hamil mendapatkan edukasi dan tingkat kepatuhan ibu terhadap konsumsi tablet $\mathrm{Fe}$ meningkat.

Angka defisiensi besi pada wanita hamil sangat tinggi dikarenakan kebutuhan akan zat besi dalam kehamilan meningkat. Sekitar 1000mg besi dibutuhkan pada kehamilan normal, 500mg dibutuhkan tubuh dalam upaya meningkatkan eritrosit untuk mengimbangi peningkatan volume darah, 300mg akan ditransfer ke fetus dan placenta, dan $200 \mathrm{mg}$ sisanya secara rutin terbuang melalui saluran pencernaaan.

Kebutuhan harian zat besi mengalami peningkatan maksimal pada paruh kedua kehamilan hingga dibutuhkan $6-7 \mathrm{mg}$ zat besi perhari. Jumlah ini tidak dapat dicukupi oleh cadangan zat besi dalam tubuh. Dengan demikian tanpa suplementasi zat besi, volume eritrosit tidak akan meningkat optimal sehingga akan terjadi anemia pada ibu.

Akan tetapi pada penelitian ini didapatkan 2 orang ibu hamil yang mengalami penurunan $\mathrm{Hb}$ dan 14 orang memiliki kadar $\mathrm{Hb}$ sama pada $\mathrm{Hb}$ awal dan akhir. Hal ini dimungkinkan karena peningkatan kadar $\mathrm{Hb}$ ibu hamil tidak semata dipengaruhi oleh tablet $\mathrm{Fe}$ semata, tetapi didukung oleh konsumsi makanan akan zat besi itu sendiri, terutama dari zat besi yang terdapat dalam hewani (absorbsinya sampai 25\%). Sayuran hijau juga merupakan sumber yang baik, ditambah buah-buahan sebagai sumber vitamin $\mathrm{C}$ yang membantu penyerapan zat besi dalam tubuh.

\section{Pengetahuan Ibu Hamil Sebelum dan Sesudah diberikan Booklet Ibu Hamil}

Pada uji analisis pengaruh penggunaan booklet ibu hamil dan tablet Fe Terhadap Pengetahuan ibu hamil korban tsunami di Kabupaten Lampung Selatan Tahun 2019 hasil output test statististik nilai Asymp.sig (2 tailed) untuk pengetahuan ibu hamil sebelum dan sesudah diberikan perlakuan sebesar 0,000 , yang berarti nilai Asymp.Sig (2 tailed) $<\rho$-value $(\rho$ value $=0,05$ ). Hasil tersebut menunjukkan bahwa Ha diterima dan Ho ditolak yang berarti ada efektivitas booklet ibu hamil dan pemberian tablet Fe terhadap pengetahuan ibu hamil korban tsunami di Kabupaten Lampung Selatan tahun 2019.

Menurut Kreuter (2000), proporsi pengetahuan yang baik akan meningkatkan kepatuhan ibu hamil dalam meminum tablet besi. Dimana kepatuhan minum tablet besi merupakan suatu bentuk perilaku yang dapat terwujud karena adanya pengetahuan yang diperoleh dari luar, salah satunya adalah dengan pemberian booklet anemia.

Puspitasari (2008) mengatakan kepatuhan ibu hamil dalam mengkonsumsi zat besi dipengaruhi oleh tingkat pengetahuan tentang manfaat dan dampak yang mungkin timbul akibat anemia zat besi pada ibu hamil. Pengetahuan sangat berpengaruh pada perilaku ibu hamil dalam menyimpan dan mengkonsumsi tablet Fe.

Pengetahuan gizi yang baik dapat menghindarkan seseorang dari konsumsi pangan yang salah (Suhardjo, 1989). Ibu hamil dengan pengetahuan gizi dan kesehatan yang baik tentunya kan dapat memilah bahan pangan yang ia konsumsi. Oleh karena itu pengetahuan akan gizi dan kesehatan yang baik dapat membantu ibu hamil menjalani masa kehamilan dengan baik pula.Dengan adanya booklet anemia, ibu hamil akan mendapatkan informasi bahwa selama kehamilan terdapat peningkatan kebutuhan zat besi hampir tiga kali lipat untuk pertumbuhan janin dan keperluan ibu hamil dan pemberian suplementasi tablet besi (Fe) selama kehamilan merupakan salah satu alternative untuk mengatasi anemia (Muhilal, 2004). Dalam 
penyuluhan dan booklet ibu hamil yang diberikan, juga terdapat penjelasan tentang manfaat, efek samping, dan cara meminimalisir efek samping yang timbul dari tablet Fe. Dengan demikian ibu mengetahui bahwa efek samping yang timbul dari konsumsi tablet $\mathrm{Fe}$ tidak membahayakan dan ibu dapat mengupayakan cara untuk meminimalisirnya.

Hal ini juga sesuai dengan penelitian Robiatul (2013) dimana terdapat perbedaan pengetahuan yang bermakna pada kelompok kotrol dan kelompok uji dengan $\rho$-value $=0,000$. Hal ini menunjukkan bahwa metode edukasi berupa pemberian booklet anemia dapat memberi peningkatan pengetahuan pada ibu hamil. Hal ini juga sesuai dengan penelitian Vernissa dkk (2017) yang menyimpulkan bahwa konseling atau pemberian leaflet pada ibu hamil dengan anemia meningkatkan kepatuhan minum Tablet Fe secara bermakna $(\rho$-value $<0,05)$. Menurut Wibowo (1992) tingkat pengetahuan merupakan salah satu pendukung yang kuat dalam pemanfaatan pelayanan antenatal. Pengetahuan sangat penting perannya dalam menentukan perilaku ibu hamil dalam menyimpan dan mengkonsumsi tablet Fe secara teratur setiap harinya. Ibu merasa ragu akan kemanfaatan tablet $\mathrm{Fe}$ disebabkan oleh efek samping yang ada.

Pada penelitian ini terdapat 4 orang responden yang memiliki tingkat pengetahuan pretest dan postest sama, kemungkinan karena responden tersebut berpendidikan SMP. Sesuai dengan teori Mubarak (2011), tidak dapat dipungkiri bahwa semakin tinggi tingkat pendidikan seseorang, semakin mudah pula mereka menerima informasi, dan pada akhirnya pengetahuan yang dimiliki akan semakin banyak.

Edukasi pasien merupakan salah satu pilar penting untuk mengoptimalkan terapi. Jika edukasi dapat dijalankan secara efektif, dapat meningkatkan pengelolaan diri sendiri oleh pasien terhadap penyakitnya. Pada penelitian ini edukasi diberikan melalui booklet ibu hamil diharapkan dapat mewakili penyampaian informasi mengenai anemia dan penggunaan tablet tambah darah (TTD) kepada ibu hamil. Booklet lebih dipilih sebagai media edukasi untuk ibu hamil karena dibandingkan dengan media edukasi visual lainnya, seperti leaflet dan poster, informasi yang terdapat di booklet dapat lebih banyak dan terinci (Roza, 2012). Dengan demikian diharapkan ibu hamil bersedia meminum semua tablet $\mathrm{Fe}$ yang diterimanya sampai habis sehingga anemia pada ibu hamil korban tsunami Lampung Selatan Tahun 2019 dapat dicegah.

\section{SIMPULAN}

Berdasarkan hasil penelitian yang dilakukan dapat ditarik kesimpulan bahwa terdapat pengaruh penggunaan media booklet ibu hamil terhadap tingkat pengetahuan ibu hamil korban tsunami di Kabupaten Lampung Selatan tahun 2019. Keterbatasan dalam penelitian ini, yaitu waktu penelitian yang tidak sesuai dengan jadwal sehingga responden yang berhasil ditemui tidak sesuai dengan saat dilakukan pra survei tetapi tidak mengurangi makna dari hasil penelitian ini.

Kementerian Kesehatan, RI. (2018). Laporan Nasional Riskesdas 2018. Jakarta: Kemenkes RI, 154-66.

Mubarak W.I. (2011). Promosi Kesehatan Untuk Kebidanan. Jakarta: Salemba Medika.

Muhilal (2004). Angka Kecukupan Mineral: Besi, Iodium, Seng, Mangan, Selenium. Jakarta.

Purbadewi, L., \& Ulvie, Y. N. S. (2013). Hubungan Tingkat Pengetahuan Tentang Anemia Dengan Kejadian Anemia Pada Ibu Hamil. Jurnal Gizi, 2(1).

Robiatul, A. (2013). Pengaruh Pemberian Booklet Anemia Terhadap 
Pengetahuan, Kepatuhan Minum Tablet Tambah Darah dan Kadar Hemoglobin Ibu Hamil. Jurnal Ilmiah Mahasiswa Universitas Surabaya, Vol.2 No.2

Roza, Fitri. 2012. Media Gizi Booklet. Padang: Poltekkes Kemenkes RI Padang.

Subagyo, HW. (2002). Hubungan Antara Status Vitamin A dan Seng Ibu Hamil dengan Keberhasilan Suplementasi Besi. (Disertasi). Semarang: Universitas Diponegoro.

Subarda, dkk. (2011). Pelayanan Antenatal Care dalam Pengelolaan Anemia berhubungan dengan Kepatuhan Ibu Hamil Minum Tablet Besi. Jurnal Gizi Klinik Indonesia, Vol 8.

Suhardjo. (1989). Sosio Budaya Gizi. Bogor: Pusat Antar Universitas Pangan dan Gizi IPB.
Triratnawati. (1998). Upaya Peningkatan Kepatuhan Ibu Hamil dalam Mengkonsumsi Pil Tambah Darah. Jurnal Epidemiologi Indonesia, Vol. 2.

Vernissa, V., Andrajati, R., \& Supardi, S. (2017). Efektivitas Leaflet dan Konseling terhadap Kepatuhan Minum Tablet Besi dan Kadar Hemoglobin Ibu Hamil dengan Anemia di Puskesmas Di Kabupaten Bogor. Media Penelitian dan Pengembangan Kesehatan, 27(4), 229-236.

Wibowo, A. (1992). Pemanfaatan Pelayanan Antenatal: Faktor-faktor yang Mempengaruhi dan Hubungannya Dengan Bayi Berat Lahir Rendah. [Disertasi]. Depok: Fakultas Ilmu Kesehatan Masyarakat, Universitas Indonesia. 